\title{
Reproductive Biology of a Tetragonopterinae (Osteichthyes, Characidae) of the Ubatiba Fluvial System, Maricá - Rj
}

\author{
Rosana Mazzoni* and Jaqueline Petito \\ Universidade do Estado do Rio de Janeiro, Instituto de Biologia / DBAV / Setor de Zoologia, Rua Sáo Francisco \\ Xavier 524, Maracanã CEP 20550-013 Rio de Janeiro, RJ - Brasil.
}

\begin{abstract}
Aspects of the reproductive biology of one Tetragonopterinae was assessed in the Ubatiba river - Maricá / RJ. Length structure and mean size suggested sexual dimorphism, females reaching larger sizes than males. The onset of sexual maturity occured at $2.8 \mathrm{~cm}$ for both the sexes. Fecundity, determined on ripe ovaries, showed positive correlation to females size and weight and varied from 595 to 5520 for $3.9 \mathrm{~cm}$ and $6.2 \mathrm{~cm}$ lengths respectively. The spawning type, defined as total, was determined by the oocyte diameter frequency from ovaries in different development stages. The frequency distribution of ovarian/testis maturation stages, associated with the temporal variation of the gonadosomatic index, suggested that the reproduction period was prolonged along the whole annual cycle.
\end{abstract}

Key words: Tetragonopterinae, coastal stream, reproductive biology.

\section{INTRODUCTION}

The Ubatiba river $\left(22^{\circ} 60^{\prime} \mathrm{S}\right.$ and $\left.42^{\circ} 48^{\prime} \mathrm{W}\right)$, together with its tributaries, Silvado, Caboclo, Fundo, Itapeteiú and Ludigério rivers, composes a small coastal fluvial system of the Brazilian East Basin in the State of Rio de Janeiro. Its main characteristic, as most of the coastal rivers, is that it is subject to sudden spates that stress local habitats and, probably, populations. More details on the thermic and hydric regimes of the Ubatiba river area can be found in Mazzoni (1998).

A total of twenty-two fish species (Costa, 1984) make up the Ubatiba river ichthyofauna, where Deuterodon sp. stands out as the main species, belonging to the Tetragonopterinae subfamily (Characidae), which is the most abundant and with widest distribution in the mentioned river (Mazzoni, 1998). This subfamily is the one with the largest number of species among the Brazilian Characidae (Britski, 1972), comprising a small sized species complex which does not exceed the $10 \mathrm{~cm}$ length (Britski et al., 1988). Its distribution includes both South and Central America, frequently grouping species of difficult identification (Lowe-McConnell, 1987). As there is no consensus on naming the Ubatiba river species, we have opted for Deuterodon sp., a wide discussion on its taxonomical position can be found in Gomes (1994).

According to the ecological theory, the reproductive strategy of a species is an adaptative character due to the environmental situation and it can vary between populations at different condiction (e.g., Stearns \& Crandal, 1984; Mann et al., 1984; Bye, 1984). Some studies on stream fish reproductive biology show very clear adaptations to the unstable conditions which prevail in the coastal streams (Garutti, 1989; Menezes \& Caramaschi, 1994). Long reproductive season, assinchronic reproduction among individuals in the population, early onset of sexual maturity and high fecundity, can be shown as the main characteristics for this condiction.

Considering these facts, the objective of this work was to describe Deuterodon sp. reproductive strategy. It would be based on the following parameters: length structure, length/weight relationship, onset of sexual maturity, fecundity and reproductive season. We also discuss the possible relationships between the reproductive strategy and the environmental characteristcs (mainly the unstable hydric regim) of the Ubatiba river.

\footnotetext{
* Author for correspondence
} 


\section{MATERIAL AND METHODS}

Monthly samples were taken from the Ubatiba river - Maricá/RJ between October/94 and September/95. Three localities were sampled according to low, medium and high sections of the river. The material comprised 460 Deuterodon sp. caught with an electric sieve, powered by an alternate current generator with a capacity of 3-4 A, 900W. The sampling procedure and its efficiency have been previously reported (Mazzoni, 1998).

Sampled fishes were conditioned in ice for transportation, processed in laboratory, and the following data were obtained: (i) standard length (SL) to the nearst $0.1 \mathrm{~mm}$ (ii) total weight (WT) to the nearst $0.1 \mathrm{~g}$ (iii) sex (iv) gonadal weight (WG) to the nearst $0.1 \mathrm{~g}$, and (v) ovarian/testis development stages. The latter one was based on vascular irrigation as well as on occupation percentage in the abdominal cavity for both the sexes. For females, oocytes presence, its size and colour was also registered and for males sperm liberation when pressing the abdomen. According to these characteristics, the following classification was considered: females immature, mature I, mature II, ripe, spawned and recovering, and males - immature, mature, ripe, spent and recovering.

Length structure was analyzed based on the number of individuals and their distribution according to size. Length/weight relationship was established considering the Ln transformed data of WT and SL ( $\mathrm{Ln}=$ neperian logarithm) and the relationship among them established through the Minimum Square method. Sexual maturity size (Lp50) was established according to Vazzoler (1981). The three previously mentioned analysis were done for males and females in separate.

Frequency distribution percentages of ovarian/testis maturation stages was used to determine species reproductive period. Maturation stages were rearranged as follows: Immature - young fish without developed gonads and SL equal or under Lp50; Nonreproductive - adult fish in maturation, mature I and II and recovering gonads; and Reproductive - ripe and partially spawned/spent gonads. Temporal variation of the female Gonadossomatic Index (GSI = WG / WT *100), was used as complementary information for the reproductive period.

Fecundity (Bagenal, 1971) was determined after counting 35 ripe females. The spawning type was evaluated according to the distribution frequency of oocytes diameter from ovaries in different maturation stages (mature I, mature II and ripe). These were measured on subsamples of $10 \mathrm{ml}$ under a stereomicroscope (x50).

\section{RESULTS}

\section{Population Structure}

Deuterodon sp. length structure indicated that males and females reached maximum lengths of $4.4 \mathrm{~cm}$ and $6.0 \mathrm{~cm}$, respectively, suggesting that females were bigger than males (Table I).

Table I. Deuterodon sp. length distribution from the Ubatiba fluvial system, Maricá - RJ. LC = length classes (cm).

\begin{tabular}{c|rr|r|r|r|r|r|r|r|r|r|r|r}
\hline LC & & $2.3 \mid-2.7$ & $2.7 \mid-3.0$ & $3.0 \mid-3.3$ & $3.3 \mid-3.6$ & $3.6 \mid-3.9$ & $3.9 \mid-4.2$ & $4.2 \mid-4.5$ & $4.5 \mid-4.8$ & $4.8 \mid-5.1$ & $5.1 \mid-5.4$ & $5.4 \mid-5.7$ & $5.7 \mid-6.0$ \\
\hline Female & $\mathrm{n}$ & 2 & 1 & 8 & 15 & 21 & 17 & 56 & 35 & 26 & 6 & 7 & 1 \\
& $\%$ & 1.03 & 0.51 & 4.10 & 7.69 & 10.77 & 8.72 & 28.72 & 17.95 & 13.33 & 3.08 & 3.59 & 0.51 \\
Male & $\mathrm{n}$ & 2 & 1 & 9 & 11 & 16 & 8 & 7 & 0 & 0 & 0 & 0 & 0 \\
& $\%$ & 3.70 & 1.85 & 16.67 & 20.37 & 29.63 & 14.81 & 12.96 & 0.00 & 0.00 & 0.00 & 0.00 & 0.00 \\
\hline
\end{tabular}

Standard length / total weight relationship indicated sexual dimorphism $(\mathrm{p}<0.01)$ as well as a high correlation of the observed points for both the sexes. The equations that explain the relationship are: $\mathrm{LnWt}=-3.58+2.95 \mathrm{LnSL}, \mathrm{r}=$ $0.95, \mathrm{n}=263, \mathrm{p}<0.01$ and $\mathrm{LnWt}=-3.18+2.58$ LnSL, $\quad r=0.89, \mathrm{n}=197, \mathrm{p}<0.01$, for females and males respectively. 
No differences were found for male and female onset of sexual maturity, so data of both the sexes were analysed together. Males and females reached sexual maturiry at $2.8 \mathrm{~cm}$ of SL.
These results suggest an absence of sexual dimorphism although females reached bigger size than male (Figure 1).

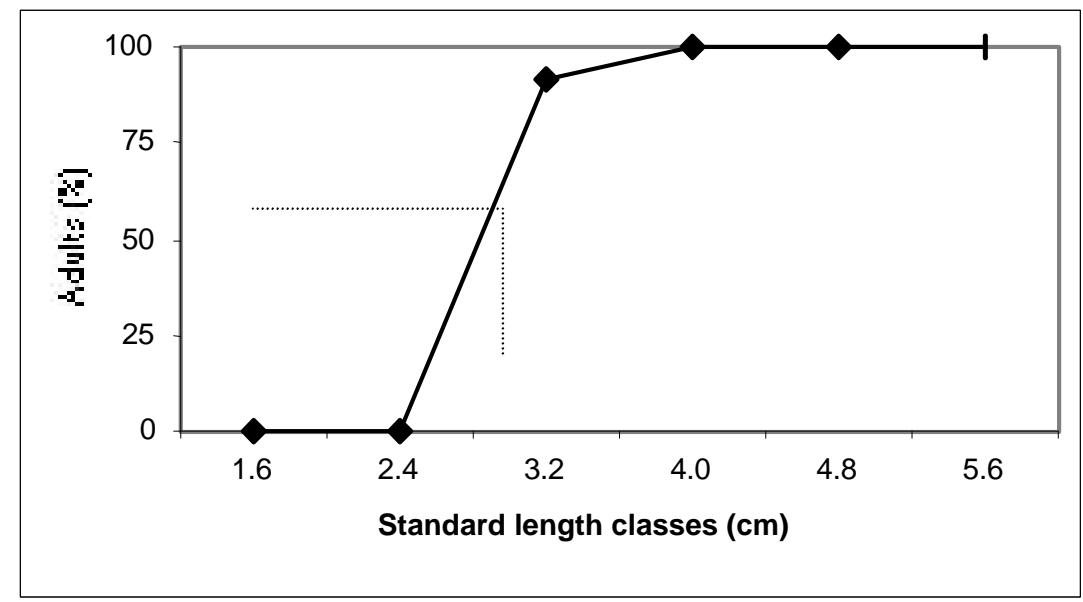

Figure 1. Length-frequency distribution of adult females and males of Deuterodon sp. The dotted line indicates the middle point of standard length class at onset of sexual maturity.

\section{Reproductive Characteristics}

Temporal variation of maturation stages indicated that immature and reproductive fishes occurred during the whole annual cycle, suggesting that reproduction was continuous all over the year being more intense from October to March (Figure 2).

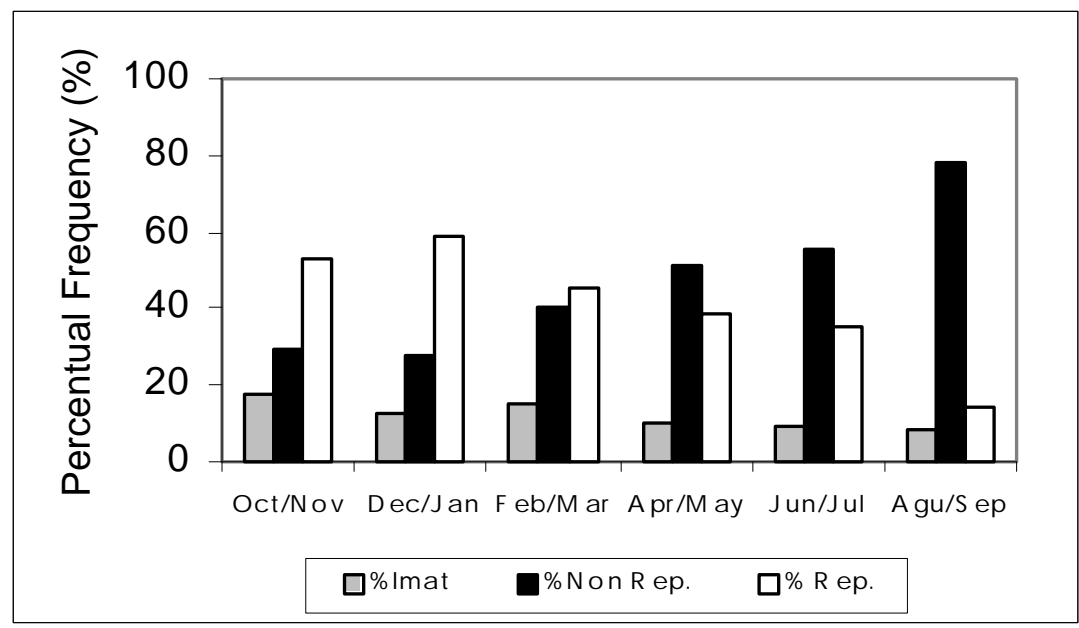

Figure 2. Temporal variation in the gonadal stages frequency of males and females of Deuterodon sp. from the Ubatiba fluvial system Maricá-RJ.

Temporal distribution of female GSI individual values corroborated the previous result and indicated the presence of reproductive fishes (GSI > 15) along the whole annual cycle. 

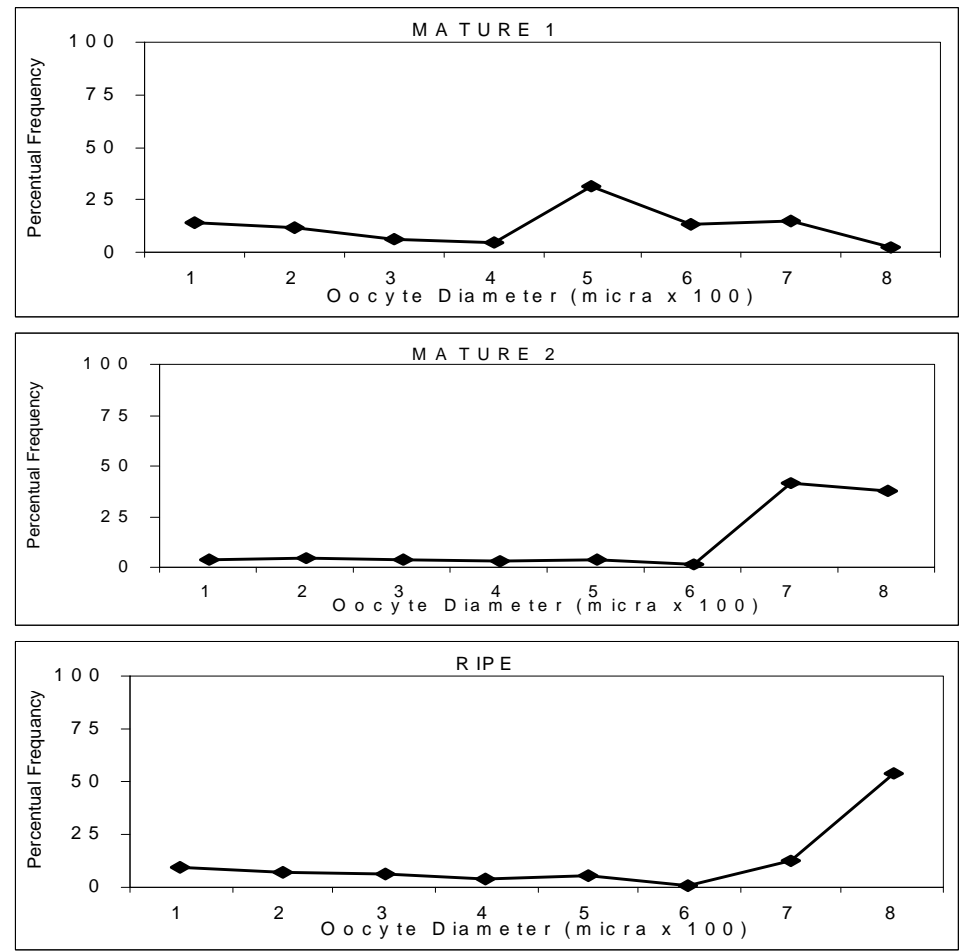

Figure 3. Oocyte size distribution of ovaries of Deuterodon sp. in different maturation stages. Numbers from 1 to 8 of the axis $\mathrm{x}$ represent the size from 100 to 800 micra

Deuterodon sp. fecundity (F) showed positive correlation with length $(\mathrm{F}=-5150.8+1574.4$ $\mathrm{SL}, \mathrm{r}=0.64, \mathrm{n}=35 ; \mathrm{p}<0.01)$ and weight $(\mathrm{F}=-$ $183.7+783.6 \mathrm{WT}, \mathrm{r}=0.77, \mathrm{n}=35 ; \mathrm{p}<0.01)$ of the females and varied from 595 to 5520 oocytes for fish of 3.9 and $6.2 \mathrm{~cm}$ respectively.

Oocyte size distribution from ovaries in different maturation stages suggested a total spawning type (Figure 3). Only one mode of 500 micra was found in mature I ovaries. The evolution of this mode was observed in mature II and ripe ovaries, 700 and 800 micra, respectively. This indicated that only one oocyte batch was recruited to maturation and only one batch was released at each reproductive event.

\section{DISCUSSION}

Fish dimorphism has been frequently discussed in the literature, body size differences between males and females were referred by Nikolsky (1963) as the most frequent form of expression of this character. Deuterodon sp. length structure from the Ubatiba river, showed female predominance in the larger SL classes, suggesting sexual dimorphism for length, with females reaching bigger sizes than males. Rodrigues et al. (1989) and Barbieri (1992), studying different Astyanax species (species correlated to Deuterodon) found similar results. Larger size among females could be interpreted as an evolutionary advantage as larger body sizes produce, potentialy, more and larger offsprings. The high correlation between SL and fecundity found in our study confirmed this.

The length / weight relationship also suggested sexual dimorphism $(p<0,05)$, females weigh more than males, when fishes of the same length were compared. Similar results were suported by Rodrigues et al. (1989) for the Astyanax bimaculatus population from Tietê Basin and by Barbieri et al. (1982) for Astyanax fasciatus and Astyanax bimaculatus.

First maturation length is defined by Vazzoler (1981) as the size in which $50 \%$ of the individuals of the population reach sexual 
maturity. According to this, we found that Deuterodon sp. males and females attained sexual maturity within the same size. Barbieri (1992) estimated $4.9 \mathrm{~cm}$ and $4.2 \mathrm{~cm}$ (females/males) as Astyanax scabripinnis paranae first reproduction size. Agostinho et al. (1984), concluded that Astyanax bimaculatus (Paraná basin) reached first maturation at $7.8 \mathrm{~cm}$ and that at $9.5 \mathrm{~cm}$ all females were able to participate in the reproduction activity. All these results showed an early onset of sexual maturity for Deuterodon sp. from the Ubatiba river.

The onset of sexual maturity has an important role to understand the life-history adopted by a species during its evolution (Stearns, 1976; Lessels, 1991). It is accepted that the optimun size for the first reproduction depends on many factors, including the relative allocation food (energy), between somatic and gonad growth (Mann et al., 1984). Interpretation of the selective forces acting on Deuterodon sp. suggests that this precocity can be related to an adaptative behaviour to compensate high juvenil losses, this is a consequence of the stressed climate that prevails in the Ubatiba river system. Such an adaptation can explain the success of a small sized species as Deuterodon sp. (it is the most abundant species in the mentioned river), when considering an unexpected environment like the Ubatiba river.

The fecundity of Deuterodon sp. Could be positively correlated to size and weight and varied from 595 to 5,520 oocytes in females between 3.9 and $6.2 \mathrm{~cm}$ respectively. Our minor values were similar to those registered by Barbieri \& Barbieri (1988) for A. bimaculatus that presented fecundity between 625 and 9,845 oocytes in females of 4.0 and $10.4 \mathrm{~cm}$ of total length. In the same way, the mean fecundity of Astyanax fasciatus was 2,144 oocytes, ranging from 680 to 4,451 in females of 5.1 and $11.4 \mathrm{~cm}$ of total length, respectively (Barbieri \& Barbieri, 1988). Barbieri (1992) concluded that the average fecundity of Astyanax scabripinnis paranae was reduced (2,239 oocytes). According to these results, we suggested that
Deuterodon sp. has fecundity values similar to the most fecund Tetragonopterinae quoted in the literature.

Temporal distribution of GSI values, as well as the presence of young fishes all over the year, suggested an uninterrupted reproduction along the annual cycle; this mean constant recruitment of young fishes in the population. The interpretation of this characteristic suggest an adaptative advantage to an unexpected environment. Continuous recruitment of young fishes is a way of guaranteeing the maintenance of species that could be subject of important losses during the sudden spates. Menezes \& Caramaschi (1994) made similar observation for Hypostomus cf. punctatus of the Ubatiba river. Corroborating our proposition, we pointed out conclusions presented by Garutti (1989) that showed an amplification of $A$. bimaculatus spawning period as the river order decreased.

Apparently contradictory to the above mentioned results, has been the total spawning type. Nevertheless, an assinchronic reproductive behaviour, among individuals in the population, has been a way of guaranteeing reproductive process all over the year. Associated to this, we observed, by histological analysis that females of Deuterodon sp. has a continuous process of maturation without recovering ovaries and very fast oocyte recruitment and maturation (unpublished data).

The Deuterodon sp. reproductive strategy could be considered as an opportunistic strategy (sensu Winemiller, 1992). Altough this was not tested in the present study, we suggest that the unexpected climatic conditions, especially the hydric regime, could probably be the main determinant for this behaviour. Following Menezes \& Caramaschi (1994) proposition, we suggest that this strategy makes the maintenance of Deuterodon sp. possible, and that, probably most of the species of this fluvial system adopt similar strategies. 


\section{AKNOWLEGDMENTS}

We thank the members of the Fish Ecology Laboratories from the Universidade do Estado do Rio de Janeiro and Universidade Federal do Rio de Janeiro for helping in the field work. Erica Pellegrini Caramaschi and Ricardo Iglesias Rios for the valuable suggestions on the whole field work, data procedure, and the manuscript. To Chiara Mazzoni for the English revision. This study is part of a Scientific Initiation work of Jaqueline Petito - CNPQ / Projeto Integrado - proc. $\mathrm{n}^{\mathrm{o}}$ 521597/95-1.

\section{RESUMO}

São avaliados alguns aspectos da biologia reprodutiva de um Tetragonopterinae do rio Ubatiba - Maricá / RJ. A estrutura em comprimento e o tamanho médio sugerem dimorfismo sexual com as fêmeas alcançando tamanhos superiores aos dos machos. A fecundidade, estabelecida a partir da análise de ovários maduros, apresenta correlação positiva com o tamanho e peso das fêmeas e variou de 595 a 5520 para os comprimentos de $3,9 \mathrm{~cm}$ e $6,2 \mathrm{~cm}$, respectivamente. O tipo de desova, definido como total, é determinado pela distribuição de frequiência do diâmetro dos ovócitos de gônadas em diferentes etapas de desenvolvimento. A distribuição da freqüência percentual de diferentes estádios de maturação, associada a variação temporal do Índice Gônado-Somático sugerem que o período de reprodução é prolongado ao longo de todo o ciclo anual com um período mais intenso nos meses de outubro a março.

\section{REFERENCES}

Agostinho, C.A., Molinari, S., Agostinho A., \& Verani, J. (1984), Ciclo reprodutivo e primeira maturação sexual de fêmeas do lambari Astyanax bimaculatus (L.) (Osteichtyes-Characidae) do rio Ivaí. Estado do Paraná. Rev. Brasil. Biol., 44(1), 31-36.

Bagenal, T.B. \& Braum, E. (1971), Eggs and Early Life History. In- Methods for Assessment of Fish Production in Fresh Waters, ed. W.E. Ricker. Blackwell Scientific Publications. IBP n.3. pp. 166-198.
Barbieri, G. (1992), Biologia de Astyanax scabripinis paranae (Characiformes, Characidae) do Ribeirão do Fazzari. São Carlos. Estado de São Paulo. I. Estrutura Populacional e Crescimento. Rev. Brasil. Biol., 52 (4), 579-588.

Barbieri,G.; Santos, M.V.R. \& Santos, J.M. (1982), Época de reprodução e relação peso/comprimento de duas espécies de Astyanax (Pisces, Characidae). Pesq. Agropec. Bras., 17(7), 10571065.

Barbieri, G. \& Barbieri, M. (1988), Curva de Maturação, Tamanho da $1{ }^{\mathrm{a}}$ Maturação gonadal e Fecundidade de Astyanax bimaculatus e Astyanax fasciatus da Represa do Lobo, estado de São Paulo (Osteichthyes, Characidae). Revista Ceres, 35 (197), 64-67.

Britski, H.A. (1972), Peixes de água doce do Estado de São Paulo. In- Comissão Interestadual da Bacia Paraná - Uruguai, Poluição $e$ Piscicultura. São Paulo, Fac. Saúde Pública da USP e Instituto de Pesca, pp. 109-112.

Britski, H.A; Sato, Y. \& Rosa, A.B.S. (1988), Manual de Identificação de peixes da região de Três-Marias, $3^{\mathrm{a}}$ Ed., CODEVASF. p.

Bye, V.J. (1984), The role of environmental factors in the timing of reproductive cycles. In- Fish Reproduction: Strategies and Tactics, ed. G.W. Potts and R.J. Wootton. Academic Press, London, pp. 187-206.

Costa, W.J.E.M. (1984), Peixes fluviais do sistema lagunar de Maricá, Rio de Janeiro, Brasil. Rev. Atlântica, 7 (4), 65-82.

Gomes, J.H.C. (1994), Distribuição, alimentação e período reprodutivo de duas espécies de Tetragonopteriane (Osteichtyes) sintópicas no rio Ubatiba (Maricá-RJ). Master Thesis, Universidade Federal do Rio de Janeiro / Museu Nacional, Brasil.

Garutti, V. (1989), Contribuição ao conhecimento reprodutivo em Astyanax bimaculatus (Ostariophysi, Characidae), em cursos de água da Bacia do Paraná. Rev. Brasil. Biol, 49(2), 489495.

Gennari-Filho, O. \& Braga, F. M. S. (1996), Fecundidade e desova de Astyanax bimaculatus $e$ A . schubarti (Characidae, Tetragonopterinae) na represa de Barra Bonita, Piracaba River (SP). Revista UNIMAR, 18(2), 241-254.

Lessels, C.M. (1991). The evolution of life histories. In- Behavioural ecologu. Na evolutionary approach, ed. J.R. Krebs \& N.B. Davies. Blackwell Scientific Publications. pp. 32-68.

Lowe-McConnell, R.H. (1987), Ecological studies in tropical fish communities. Cambridge University Press.

Mazzoni, R. (1998), Estrutura das Comunidades e Produção de Peixes de um Sistema Fluvial Costeiro de Mata Atlântica, Rio de Janeiro. PhD 
Thesis, Universidade Federal de São Carlos, São Paulo, Brasil.

Menezes, M.S. \& Caramaschi, E.P. (1994), Características reprodutivas de Hypostomus gr. Punctatus do rio Ubatiba, Maricá - RJ (Osteichthyes, Siluriformes). Rev. Brasil. Biol., 54, 503-513.

Mann, R.H.K.; Mills, C.A. \& Crisp, D.T. (1984), Geographical variation in the life-history tactics of some species of freshwater fishes. In- Fish Reproduction: Strategies and Tactics, ed. G.W. Potts and R.J. Wootton. Academic Press, London, pp. 171-186.

Nikolsky, G.V. (1963), The Ecology of Fishes. Acad. Press.

Rodrigues, A.M.; Rodrigues, J.D. \& Ferreira, A.E. (1989), Aspectos da estrutura populacional e época de reprodução do tambiú Astyanax bimaculatus (Characiformes, Characidae) na represa de Bariri, rio Tietê, estado de São Paulo, Brasil. Bol. Inst. Pesca, 16(1), 97-110.

Santos, R.A.; Campos, E.; Camara, J. \& MandelliJúnior, J. (1991), Curvas de maturação gonadal e crescimento de fêmeas de tambiú Astyanax bimaculatus LINNAEUS, 1758 (Characiformes, Craracidae), na represa de Ibitinga, Estado de São Paulo, Brasil. Bol. Inst. Pesca, 18, 1-11.

Stearns, S.C. (1976), Life history tactics: a review of the ideas. Q. Ver. Biol., 51, 3-47.

Stearns, S.C. \& Crandall, R.E. (1984), Plasticity for age and size at sexual maturity: a life-history response to unavoidable stress. In- Fish Reproduction: Strategies and Tactics, ed. G.W. Potts and R.J. Wootton. Academic Press, London, pp. 13-34.

Winemiller, K.O. \& Rose, K.A. (1992). Patterns of life-history diversification in North American fishes: implications for population regulation. Can. J. Fish. Aquat. Sci., 49, 2196-2218.

Vazzoller, A.E.A. de M. (1981), Manual e métodos para estudos biológicos de populações de peixes. Reprodução e Crescimento. Brasília, CNPq / Programa Nacional de Zoologia.

Received: January 06, 1999; Revised: January 14, 1999; Accepted: August 27, 1999. 